\title{
Lactoferrin levels in normal human tears
}

\author{
A. KIJLSTRA, S. H. M. JEURISSEN, AND K. M. KONING \\ From the Department of Ophthalmology, Netherlands Ophthalmic Research Institute, Amsterdam, \\ The Netherlands
}

SUMMARY Using commercially available reagents we developed an enzyme-linked immunosorbent assay to measure lactoferrin in normal human tears. Tears obtained from 38 normal human subjects contained a mean lactoferrin content of $2.2 \mathrm{mg} / \mathrm{ml}(\mathrm{g} / \mathrm{l})$. No differences in the mean level of lactoferrin were found when tears were collected by either Schirmer tear strips or by glass capillaries after short tear gas stimulation. Tear lactoferrin levels were not influenced by age or sex of the subjects investigated in this study. We found that lactoferrin represents approximately $25 \%$ by weight of the total tear proteins.

Hurnan tears contain a variety of proteins involved in the defence against invading micro-organisms. One of the proteins in nonspecific defence, lactoferrin, was first described in human tears by Masson et al. ${ }^{\prime}$ The acinar epithelium of the main and accessory lacrimal glands was later shown to be the source of lactoferrin in normal human tears. ${ }^{23}$

Lactoferrin can reversibly bind 2 atoms of iron. This is thought to be responsible for the antibacterial properties of this protein. In addition to its known bacteriostatic effects we have recently shown that tear lactoferrin has a strong inhibitory effect on the classical complement system ${ }^{45}$ and might thus also have anti-inflammatory properties. Although the presence of lactoferrin in tears has been known for some time, only estimates of its quantity have been reported until now. ${ }^{67}$

To investigate the biological role of this protein in the normal and diseased eye a method was required for accurately determining its level in human tears. We have therefore developed a simple quantitative assay utilising commercially available reagents to determine the level of tear lactoferrin in human tears.

\section{Materials and methods}

Tear samples were obtained from staff members of our institute. A sample of $2 \mu \mathrm{l}$ was collected after short stimulation with tear gas (chloroacetophenon) with a graded $5 \mu$ l glass capillary and immediately mixed with $1.0 \mathrm{ml}$ of phosphate buffer $(\mathrm{pH} 7,4)$ containing $4 \%$ bovine serum albumin, $1.0 \mathrm{M}$ sodium Correspondence to Dr A. Kijlstra, Department of Ophthalmic Immunology, PO Box 6411, 1005 EK Amsterdam, The Netherlands. chloride and $0 \cdot 1 \%$ Tween 20 (incubation buffer). Tear samples were also collected with calibrated Schirmer tear strips. The wet strip was cut off so as to contain $10 \mu \mathrm{l}$ of tears and immediately placed in 0.49 $\mathrm{ml}$ incubation buffer. Control studies whereby known lactoferrin concentrations were applied on Schirmer tear strips showed that over $90 \%$ of the lactoferrin was eluted from the strips by this procedure.

Lactoferrin in the diluted tear samples was determined by an enzyme-linked immunosorbent assay (ELISA). The method used is based on a competition between solid-phase (constant) and fluid-phase (experimental) lactoferrin for a rabbit anti-human lactoferrin antibody. The solid phase bound rabbit antibody is subsequently measured with a peroxidase-coupled goat anti-rabbit immunoglobulin antibody. The details of the assay are as follows: plastic microcuvettes were coated with lactoferrin by incubating them for one hour at room temperature with a $300 \mu$ l solution of a commercial preparation of human milk lactoferrin $(5 \mu \mathrm{g} / \mathrm{ml})$ in coating buffer $\left(1.6 \mathrm{~g} \mathrm{Na}_{2} \mathrm{CO}_{3}, 2.9 \mathrm{~g} \mathrm{NaHCO}_{3}, 0.2 \mathrm{~g}\right.$ $\mathrm{NaN}_{3}$ in $11 \mathrm{H}_{2} \mathrm{O}$, pH 9.6).

After coating the cuvettes they were rinsed 3 times with phosphate-buffered saline (PBS) containing $0 \cdot 1 \%$ Tween 20 (PBS-Tween). To the empty cuvettes we subsequently added $200 \mu$ l of a diluted $(1 / 500)$ tear sample or tear lactoferrin standards in incubation buffer $(0-20 \mu \mathrm{g} / \mathrm{ml})$, which was followed by $200 \mu \mathrm{l}$ of a 1/1000 dilution of a rabbit anti-human lactoferrin antibody preparation (in PBS-Tween). The cuvettes were incubated in a $37^{\circ} \mathrm{C}$ shaking waterbath for one hour and rinsed 3 times in PBS-Tween. Then $300 \mu$ l of $1 / 500$ dilution (in PBS-Tween) of a commercially 
available peroxidase-coupled goat anti-rabbit immunoglobulin antibody was added and incubation was continued for one hour at $37^{\circ} \mathrm{C}$. Cuvettes were rinsed 3 times, and bound peroxidase-labelled antibody was developed at room temperature by adding $350 \mu \mathrm{l}$ ABTS solution $\left(0 \cdot 16 \mathrm{mM} 2 \cdot 2^{\prime}\right.$-azino-di(3-ethyl-benzthiazoline-6-sulphonate), $0 \cdot 12 \% \quad \mathrm{H}_{2} \mathrm{O}_{2}$ in $0.05 \mathrm{M}$ citric acid $\mathrm{pH} 4.0$ ). The reaction was stopped by adding $175 \mu \mathrm{l}$ of stopping reagent $(0 \cdot 1 \mathrm{M} \mathrm{HF}, 0 \cdot 01$ $\mathrm{M} \mathrm{NaOH}$, and 0.001 M EDTA). The green reaction product was measured in a spectrophotometer at 405 $\mathrm{nm}$. Controls included uncoated cuvettes incubated with the lactoferrin standards, and coated cuvettes incubated with buffer alone ( $0 \%$ inhibition) or a high concentration $(0.5 \mathrm{mg} / \mathrm{ml})$ of purified tear lactoferrin resulting in $100 \%$ inhibition.

A standard curve was obtained by plotting the extinction at $405 \mathrm{~nm}$ on a normal scale against the lactoferrin standard on a logarithmic scale. All experimental samples and standards were tested in triplicate.

The slopes obtained for standard curves employing a commercially available lactoferrin standard (36 $\mu \mathrm{g} / \mathrm{ml})$, milk lactoferrin standards $(0-20 \mu \mathrm{g} / \mathrm{ml})$, isolated tear lactoferrin $(0-20 \mu \mathrm{g} / \mathrm{ml})$, and a range of dilutions $(1 / 250,1 / 500$, and $1 / 1000)$ of normal human tear samples obtained from 3 different individuals were all identical. (SI conversion: $\mu \mathrm{g} / \mathrm{ml}=\mathrm{mg} / \mathrm{l}$.)

Tear lactoferrin was isolated from normal human tears as described earlier, ${ }^{4}$ whereby the concentration of the isolated protein was calculated with the above mentioned assay with the commercially available lactoferrin standard as a reference. The lactoferrin content of the purified protein as measured with the ELISA was identical to that determined with the Bradford protein assay using bovine serum albumin as a standard.

Sucrose gradient centrifugation of tear samples was performed by layering $300 \mu \mathrm{l}$ samples (obtained after tear gas stimulation) on a $10 \%$ to $30 \%$ sucrose gradient $(12.0 \mathrm{ml})$ and centrifugation for 24 hours at $40000 \mathrm{rpm}$. After centrifugation the gradients were fractionated into 16 fractions and analysed for total protein, lysozyme, $\operatorname{IgA}$, albumin, and lactoferrin. Total protein was assayed with the Bradford method with isolated tear lactoferrin as a standard. IgA was assayed by radial immunodiffusion and serum albumin by Ouchterlony analysis. Lactoferrin was assayed by the ELISA method and by Ouchterlony analysis. Lysozyme was measured by Mrs E. Glasius of the Biochemical Laboratory of our institute using the Micrococcus lysodeiticus assay with chicken lysozyme as a standard. Furthermore various fractions were analysed by sodium dodecylsulphate (SDS)-polyacrylamide gel electrophoresis as described earlier. ${ }^{4}$
The relative amount of lactoferrin in human tears was measured by collecting $10 \mu \mathrm{l}$ of tears with calibrated Schirmer tear strips and immediately placing the wet strips in $1.0 \mathrm{ml} 0.5 \mathrm{M}$ sodium chloride in phosphate buffer, $\mathrm{pH} 7 \cdot 4$. After being eluted for 15 minutes at room temperature, the total protein (Bradford assay) and lactoferrin (ELISA) content were measured as indicated.

\section{Results}

Specificity controls of the ELISA for tear lactoferrin showed that standard curves obtained with various dilutions of isolated tear lactoferrin, milk lactoferrin, lactoferrin reference serum, and normal human tears had identical slopes. Dose response curves showed that reproducible results were obtained in a concentration range between 1 and $20 \mu \mathrm{g} / \mathrm{ml}(\mathrm{g} / \mathrm{l})$ of lactoferrin. Further specificity controls were performed by subjecting tears to sucrose gradient ultracentrifugation and subsequently analysing individual fractions for their lactoferrin content (Fig. 1). Only a small peak sedimenting in fraction 8-11 was

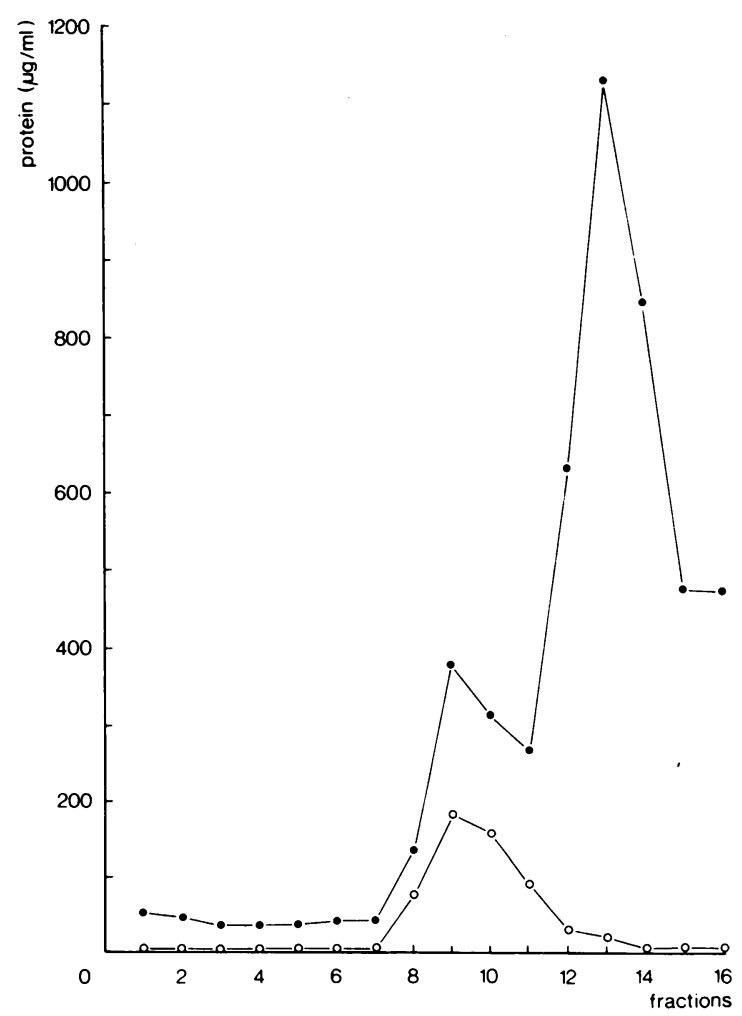

Fig. 1 Sucrose gradient ultracentrifugation of stimulated normal human ears. Total protein $-\bullet$. Lactoferrin $\mathrm{O}-\mathrm{O}$. 


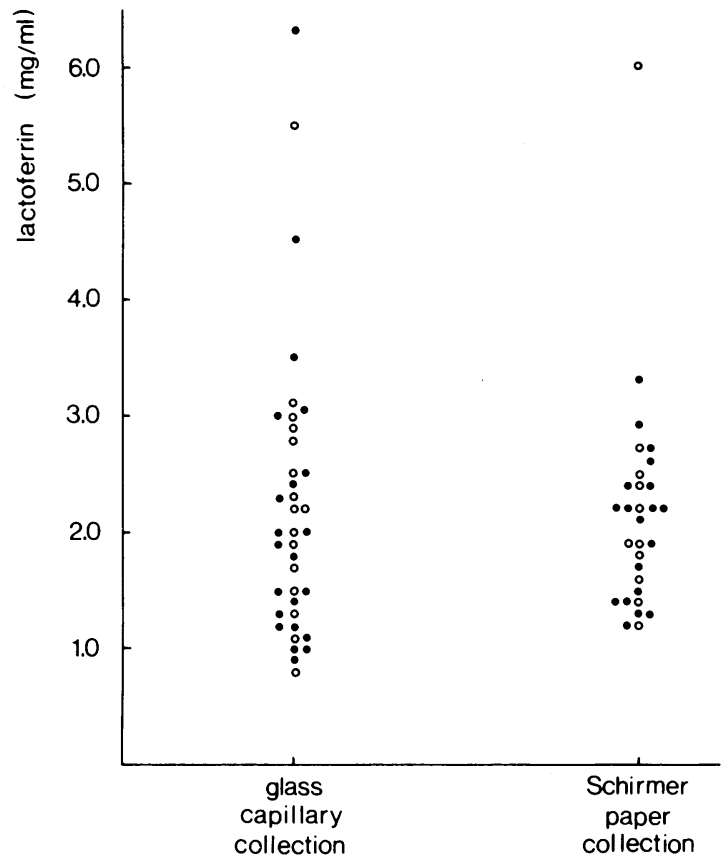

Fig. 2 Lactoferrin levels in human tears collected by glass capillaries after short tear gas stimulation or with Schirmer tear strips. Male subjects $\mathbf{0}$. Female subject $\bigcirc$.

shown to contain lactoferrin by the ELISA method described. SDS-polyacrylamide gel electrophoresis and Ouchterlony analysis showed that this small peak mainly contained 2 proteins, namely, lactoferrin and serum albumin. Separate experiments showed that isolated serum albumin did not interfere with the lactoferrin ELISA. The large protein peak sedimenting in fractions 11 to 15 contained lysozyme as detected by the lysis of Micrococcus lysodeiticus. IgA sedimented at the bottom of the sucrose gradient in fraction 1 to 5 .

The experiments thus show that the ELISA method employed is specific for lactoferrin and is not interfered with by other proteins in normal human tears. With the enzyme-linked immunosorbent assay described we measured the lactoferrin content in tear samples obtained from normal human individuals. Fig. 2 shows the values obtained in tears collected with glass capillaries after short stimulation with tear gas. The mean age of these tear donors (16 women and 22 men) was 32 years and ranged between 17 and 61 years. The level of lactoferrin in these stimulated tears was $2 \cdot 22 \pm 1 \cdot 21 \mathrm{mg} / \mathrm{ml}($ mean $\pm 1 \mathrm{SD})$. There was a large variation of the levels; the lowest and highest values being $0.8 \mathrm{mg} / \mathrm{ml}$ and $6.3 \mathrm{mg} / \mathrm{ml}$ respectively. No statistically significant difference was found between the lactoferrin content in the stimulated tears of men $(2 \cdot 15 \pm 1 \cdot 31 \mathrm{mg} / \mathrm{ml}$; mean \pm 1 SD) and
Table 1 The relative amount of lactoferrin in human tears collected by Schirmer tear strips

\begin{tabular}{llll}
\hline Subject & $\begin{array}{l}\text { Total protein } \\
(\mathrm{mg} / \mathrm{ml})\end{array}$ & Lactoferrin $(\mathrm{mg} / \mathrm{ml})$ & \% Lactoferrin \\
\hline 1 & $12 \cdot 6$ & $3 \cdot 4$ & $27 \cdot 0$ \\
2 & $11 \cdot 5$ & $2 \cdot 4$ & $20 \cdot 9$ \\
3 & $11 \cdot 4$ & $1 \cdot 8$ & $15 \cdot 8$ \\
4 & $11 \cdot 0$ & $2 \cdot 2$ & $20 \cdot 0$ \\
5 & $9 \cdot 5$ & $2 \cdot 8$ & $29 \cdot 5$ \\
6 & $9 \cdot 2$ & $2 \cdot 3$ & $25 \cdot 0$ \\
7 & $8 \cdot 5$ & $2 \cdot 1$ & $24 \cdot 7$ \\
8 & $8 \cdot 4$ & $2 \cdot 5$ & $29 \cdot 8$ \\
9 & $7 \cdot 7$ & $2 \cdot 2$ & $28 \cdot 6$ \\
10 & $6 \cdot 8$ & $2 \cdot 0$ & $29 \cdot 4$ \\
Mean \pm 1 SD & $9 \cdot 6 \pm 1 \cdot 8$ & $2 \cdot 4 \pm 0 \cdot 45$ & $25 \cdot 1 \pm 4 \cdot 8$ \\
\hline
\end{tabular}

SI conversion: $\mathrm{mg} / \mathrm{ml}=\mathrm{g} / \mathrm{l}$.

that of the women $(2 \cdot 3 \pm 1 \cdot 09 \mathrm{mg} / \mathrm{ml}$, mean $\pm 1 \mathrm{SD})$ tested. Nor could we find a correlation between lactoferrin level and the age of the subjects investigated in this study.

Because for clinical studies the use of Schirmer tear strips to obtain tears has practical advantages over the technique whereby stimulated tears are obtained with glass capillaries, a comparison was made of lactoferrin levels in samples collected by these 2 methods.

The results obtained with tear samples eluted from the Schirmer strips are presented in Fig. 2. The group of subjects tested $(n=30)$ consisted of 19 men and 11 women with a mean age of 33 years. The lactoferrin level in these tear samples $(2.15 \pm 0.91 \mathrm{mg} / \mathrm{ml}$ (mean $\pm 1 \mathrm{SD}$ ) was not significantly different from those obtained with glass capillaries. And in these eluted tear samples no correlation was found between tear lactoferrin levels and the sex and age of the investigated subjects.

To investigate the contribution of lactoferrin to the total tear proteins the following experiment was performed: tear samples were collected with Schirmer tear strips from 10 different subjects, and concentrations of total protein and lactoferrin were determined in each sample. The results (Table 1) show that lactoferrin represents 15 to $30 \%$ of the total tear proteins, with a mean of $25 \cdot 1 \%$.

\section{Discussion}

The studies described here show that tear lactoferrin is abundantly present in normal human tears. With a mean concentration of approximately $2 \mathrm{mg} / \mathrm{ml}(\mathrm{g} / \mathrm{l})$ it represents one of the main proteins in human tears. To measure tear lactoferrin we propose an enzymelinked immunosorbent assay which can be performed with commercially available reagents. The determination of lactoferrin in tears by radial immunodiffusion, which is a simpler technique than the 
ELISA, is hampered by the fact that lactoferrin binds to agar and agarose,${ }^{78}$ leading to erroneous results. In the ELISA procedure described here high concentrations of sodium chloride and bovine serum albumin are used to eliminate aspecific interactions with the solid phase. The observation that the standard curves of isolated tear lactoferrin, milk lactoferrin, and human tears have identical slopes indicates that no other substances than lactoferrin are detected. Furthermore sucrose gradient ultracentrifugation showed that only one lactoferrin peak could be detected with the ELISA, a finding that was confirmed by SDS-polyacrylamide gel electrophoresis and immunoprecipitation.

Lactoferrin is considered to play an important role in nonspecific defence against a variety of bacteria. ${ }^{910}$ Although it was initially thought that the antibacterial effect was due to the iron binding capacity of lactoferrin, recent studies indicate that lactoferrin also has a direct effect on certain bacterial strains. ${ }^{11}$ Besides its role in bacterial immunity lactoferrin has been shown to play a role in the regulation of the production of granulocyte- and macrophage-derived colonystimulating factors. ${ }^{12} 13$

Furthermore we recently showed that tear lactoferrin can inhibit the formation of the classical C3 convertase of the complement system and thus can prevent the formation of the biologically active complement fragments $\mathrm{C} 3 \mathrm{a}$ and $\mathrm{C5a}$. This latter function of lactoferrin may prevent complement activation on the external surface of the eye in those inflammatory conditions whereby serum leaks into the tear film. The observation that high levels of lactoferrin have been found in inflammatory sites such as bronchial secretions in patients with chronic pulmonary disease ${ }^{14}$ and in exudates of arthritic joints ${ }^{15}$ suggests that lactoferrin may play a role in inflammation. Experiments on animals and the determination of lactoferrin levels in the tears of patients with various eye diseases will give more insight into the physiological role of lactoferrin in the tear film.

\section{References}

1 Masson PL, Heremans JF, Dive C. An iron binding protein common to many external secretions. Clin Chim Acta 1966; 14: 735-9.

2 Franklin RM, Kenyon KR, Tomasi TB. Immunohistologic studies of human lacrimal gland: localization of immunoglobulin, secretory component and lactoferrin. J Immunol 1973; 110: 984-92.

3 Gilette TE, Allansmith MR. Lactoferrin in human ocular tissues. Am J Ophthalmol 1980; 90: 30-7.

4 Veerhuis R, Kijlstra A. Inhibition of hemolytic complement activity lactoferrin in tears. Exp Eye Res 1982; 34: 257-65.

5 Kijlstra A, Jeurissen SHM. Modulation of classical C3 convertase of complement by tear lactoferrin. Immunology 1982; 47: 263-70.

6 Broekhuyse RM. Tear lactoferrin: a bacteriostatic and complexing protein. Invest Ophthalmol Visual Sci 19074; 13: 550-4.

7 Malmquist J. Johansson BG. Interaction of lactoferrin with agar gels and with trypan blue. Biochim Biophys Acta 1971; 226: 38-46.

8 Hekman A. Association of lactoferrin with other proteins, as demonstrated by changes in electrophoretic mobility. Biochim Biophys Acta 1971; 251: 380-7.

9 Arnold RR, Cole MF. McGhee JR. A bactericidal effect for human lactoferrin. Science 1977; 197: 263-5.

10 Bullen JJ, Armstrong JA. The role of lactoferrin in the bactericidal function of polymorphonuclear leukocyte. Immunology 1979; 36: 781-91.

11 Arnold RR, Russell JE. Champion WJ. Brewer M. Gauthier JJ. Bactericidal activity of human lactoferrin: differentiation from the stasis of iron deprivation. Infect Immun 1982; 35: 792-9.

12 Broxmeyer HE, Smithyman A, Eger RR, Meyer PA, de Sousa $M$. Indification of lactoferrin as the granulocyte-derived inhibitor of colony-stimulating production. J Exp Med 1978; 148: 1052.

13 Badgy GC, Rigas VD, Bennet RM, Vandenbark AA. Garewal HS. Interaction of lactoferrin, monocytes, and T-lymphocyte subsets in the regulation of steady-state granulopoiesis in vitro. $J$ Clin Invest 1981: 68: 56-63.

14 Zebrak J, Herman T, Werys R, Pryjma J, Gawel J. Proteins in bronchial secretion of children with chronic pulmonary disease. II. Relation to bronchoscopic and bronchographic examination. Scand J Resp Dis 1979; 60: 69-75.

15 Malmquist J. Thovell JI. Wollheim FA. Lactoferrin and lysozyme in arthritic exudates. Acta Med Scand 1977; 202: 313-8. 